\title{
EFFECT OF PRE DRYING AND USING HYDROCOLLOID SYSTEM ON FRYING CHARACTERISTICS OF FRIED POTATO
}

\author{
Khaled Abu-Alruz \\ Department of Nutrition and Food Technology, \\ Faculty of Agriculture, Mu'tah University, Al-Karak, Jordan
}

Received 2013-09-19, Revised 2013-10-12; Accepted 2013-10-18

\begin{abstract}
This study investigated the interaction effect of pre drying treatments and using hydrocolloids mixture as an edible coat, as a packaging material and for better frying results for fried potato. Pre drying treatments used were heating samples at $69^{\circ} \mathrm{C}$ for 3 and 25 min. Hydrocolloid system used was MA- 1 type, Hydrocolloid GENU ${ }^{\circledR}$ texturizer contains; methylcellulose, carrageenan and potassium chloride. Treatments were evaluated by measuring oil content, moisture content, cutting force, color and mold growth. The result showed a great effect for the hydrocolloid system in combination of pre drying treatment $\left(69^{\circ} \mathrm{C}\right.$ for $\left.25 \mathrm{~min}\right)$ in both prolonging the fried product shelf-life through retarding and decreasing mold formation and in enhancing the frying characteristics; oil-uptake (reduced by $39.33 \%$ ), moisture loss (reduced by $25.83 \%$ ) and texture. The treatments did not significantly affect the color of fried potato samples.
\end{abstract}

Keywords: Frying Characteristics, Hydrocolloids, Edible Coat, Pre Drying

\section{INTRODUCTION}

Deep-fat frying is a process for cooking foods by immersing them in an edible oil or fat heated above the boiling point of water (Farkas et al., 1996). Due to public health concerns, there is a strong demand to reduce the oil content of fried foods (Bunger et al., 2003). Ouchon and Pyle (2004) stated that low fat snack products are of primary concern and will probably be the driving force of the snack industry during the next few years.

Numerous studies have reported that oil uptake is limited to the surface of the fried product and restricted to a depth of a few cells and that oil uptake would mainly occur once the food is removed from the oil bath and begins to cool, since the vigorous escape of water would preclude the absorption during most of the immersion period (Moreno and Bouchon, 2008).

To reduce oil content in fried food, there are two mechanisms could be used. First: Removal of surface oil before the suction takes place by using hot air drying and super-heated steam drying (Ouchon and
Pyle, 2004). Second: modifying surface permeability which can be achieved by using edible film coating (Rimac-Brncic et al., 2004; Bunger et al., 2003). Edible films are of special interest because they possess good barrier properties to oxygen, carbon dioxide and lipids (Albert and Mittal, 2002). Edible coatings and films comprise a unique category of packaging materials differing from other packaging materials and from conventional packaging by being edible (Weber, 2000). Edible coatings are applied and formed directly on the food product by different applications. They may be applied with the following procedures: a paintbrush, by spraying, dipping or fluidizing (Cuq et al., 1995). Edible coatings form an integral part of the food product and hence should not impact on the sensory characteristics of the food (Guilbert et al., 1997). Materials used to make edible films include polysaccharides, proteins and lipids or combinations of these compounds (Kester and Fennema, 1986).

Cellulose and its derivatives such as ethers and esters are, with starch, the most important and useful 
raw materials for the preparation of edible coats (Bravin et al., 2004; Rimac-Brncic et al., 2004). Methylcellulose (MC) is the methyl ether of cellulose. It is prepared from wood pulp or cotton by treatment with alkali and methylation of the alkali cellulose with methyl chloride. The advantage of using methylcellulose as edible coat material is for the good film-forming properties, which decrease the two mass-transfer namely; water and oil. Carrageenan is a hydrocolloid consisting mainly of calcium, magnesium, potassium and sodium sulphate esters of galactose and 3.6 anhydrogalactose copolymers. It is manufactured by aqueous extraction from certain members of the class Rhodophyceae (red seaweeds). The advantage of using carrageenan as edible coat material is to provide consistency to the coat, thus decrease gas and moisture transfer. Potassium chloride used to enhance the bounding reactions between the hydrocolloids. Albert and Mittal (2002) evaluated nine hyrocolloids and reprted that composite coatings with mixed materials gave the best results for decreasing oil uptake as compared to multible layers coatings. Bravin et al. (2006) reported that edible film deposition method affect the physical performance of the film. Little studies investigated the effect of pretreatments on the physical performance of the edible film. One of the pretreatments is partial drying of sample before the application of the edible film. Krokida et al. (2001) pointed that pre-fry drying decreases the oil content of potato stripes during frying. Garmakhany et al. (2010) reported that potato variety have a significant impact on the effect of pre-fry drying.

This aim of this research was to investigate the effect of pre drying treatments in combination with hydrocolloid system consist of; Methylcellulose (MC), Carrageenan and Potassium chloride on the shelf-life of fried potato and on its frying characteristics.

\section{MATERIALS AND METHODS}

\subsection{Materials}

Potato samples bought from local market, Sunflower oil bought from local market for frying process, Hydrocolloid GENU $^{\circledR}$ texturizer type MA-1 from Hercules Copenhagen A/S, DK-4623 Lille Skensved, Denmark.

\subsection{Methods}

\subsubsection{Hydrocolloid Preparation}

A $0.5,1,1.5$ and $5 \%$ hydrocolloids solutions were prepared to choose the best concentration. Hydrocolloids powder (Type MA-1) purred gradually to water under agitation by using colloidal mill (Silverson, USA) at maximum speed. The amount of hydrocolloid powder added each time was very small to avoid caking. The best sensory characteristics of potato samples were obtained with using the $1.5 \%$ solution. Thus $1.5 \%$ concentration was chosen to run this experiment.

\subsection{Production of French Fries}

Cylindrical potato samples were dried (UF30; Memmert, Jermany) partially for $3 \mathrm{~min}$ and other samples for $25 \mathrm{~min}$ at $69^{\circ} \mathrm{C}$. The partially dried samples were soaked for $3 \mathrm{~min}$ in the coating solutions and become rehydrated. The frying experiments were performed in a temperature controlled experimental deep-fat fryer of 2 liter capacity (Moulinex, France) with sunflower oil as the frying medium. The fryer was set to the required operating temperature $\left(160^{\circ} \mathrm{C}\right)$ and allowed to stabilize for approximately $1 \mathrm{~h}$ to ensure steady-state conditions. The rehydrated samples were immersed in the hot oil and fried for a predetermined period of time $(3 \mathrm{~min})$. After frying samples for the specified time at the required operating conditions, it was removed from the unit and the excess surface oil absorbed with tissue paper. After allowing the samples temperature to stabilize at room temperature, it was weighed and samples were drawn for subsequent tests.

\subsection{Analytical Methods}

Fried samples were placed in paper bags and left open and stored at room temperature. Each sample was observed for the formation of mold growth daily for one week.

The oil content (\%, dry basis) and moisture contents $(\mathrm{kg} / \mathrm{kg}$, dry basis) of the sample were then determined using Soxhlet method, moisture content determination method according to AOAC (AOAC, 1995), respectively.

Moisture loss (\%) was calculated according to the following formula: [(sample moisture content before frying/sample moisture content after frying)-1] x 100.

Rduction in fat absorption (\%) was calculated according to the following formula: [(fat content $(\%)$ in treatment sample/ fat content $(\%)$ in control sample)-1] $\mathrm{x}$ 100.

For color analysis, Hunter lab system (Data color 3, Text flesh, USA) was used. Total color difference $(\Delta \mathrm{E})$ was calculated according to the following formula:

$$
\Delta \mathrm{E}=\left[\left(\Delta \mathrm{L}^{2}\right)+\left(\Delta \mathrm{a}^{2}\right)+\left(\Delta \mathrm{b}^{2}\right)\right]^{1 / 2}
$$


Texture analysis was performed using Instron (1140, UK) using Instron Universal Material Testing System.

All experiments were conducted in 4 replications and results were analyzed using SAS system software (2001). Means separation was performed using Duncan multiple range test with a confidence level of $95 \%$.

\section{RESULTS AND DISCUSSION}

\subsection{Oil and Moisture Content}

Figure 1 and 2 and Table 2 show the oil and moisture content data for control and samples pre dried for different times and soaked in hydrocolloid solution prior to frying. Samples soaked in hydrocolloid solution presented a reduced moisture loss during frying, which in turn lessened the oil uptake. This is due to the hydrocolloid acting as a gel forming material. As a consequences of heat, the hydrocolloid starts gelatinizing around the potato cylinder surface, thus forming a barrier for mass transfer; moisture from the sample and oil into the sample. Rimac-Brncic et al. (2004) proposed that the ability of CMC derivatives to reduce oil uptake could be apart others due to the increase in water-holding capacity by entrapping moisture and consequently due to prevention of moisture replacement by oil. Table 1 shows the associated equations representing the moisture loss data.
A partial drying step, for longer period of time, may enhance the effect of dipping in hydrocolloid solution on the frying characteristics and packaging effect. As shown in Table 2, there was a significant decrease in moisture loss after frying from $31.18 \%$ to $25.83 \%$ for samples pre dried for 3 and $25 \mathrm{~min}$ respectively. As a result, oil absorption also significantly affected. As compared to control sample, the percentage of reduction of oil content were $22.75 \%$ for sample pre dried for $3 \mathrm{~min}$ and $39.33 \%$ for sample pre dried for $25 \mathrm{~min}$. The positive effect of pre drying step could be related to absorption of greater amount of hydrocolloid beneath the surface as well as the surface of samples during rehydration step (dipping in hydrocolloid solution). Therefore, the effect of hydrocolloid found to be greater on decreasing oil and moisture transfer. Another reason is that predrying decreases the moisture content in potato before frying, Krokida et al. (2001) Pointed that pre-fry drying reduces the initial moisture content of french fries. Therefore, increased duration of pre-drying implies that less amount of free moisture is available for removal during frying and less amount of oil is absorbed. Thus the pre-fry drying decreases the oil content of potato strips during frying. Garmakhany et al. (2010) reported that pre drying treatment decrease oil uptake in fried potato by blocking of capillary tubes and collapse of the porous structure of potato.

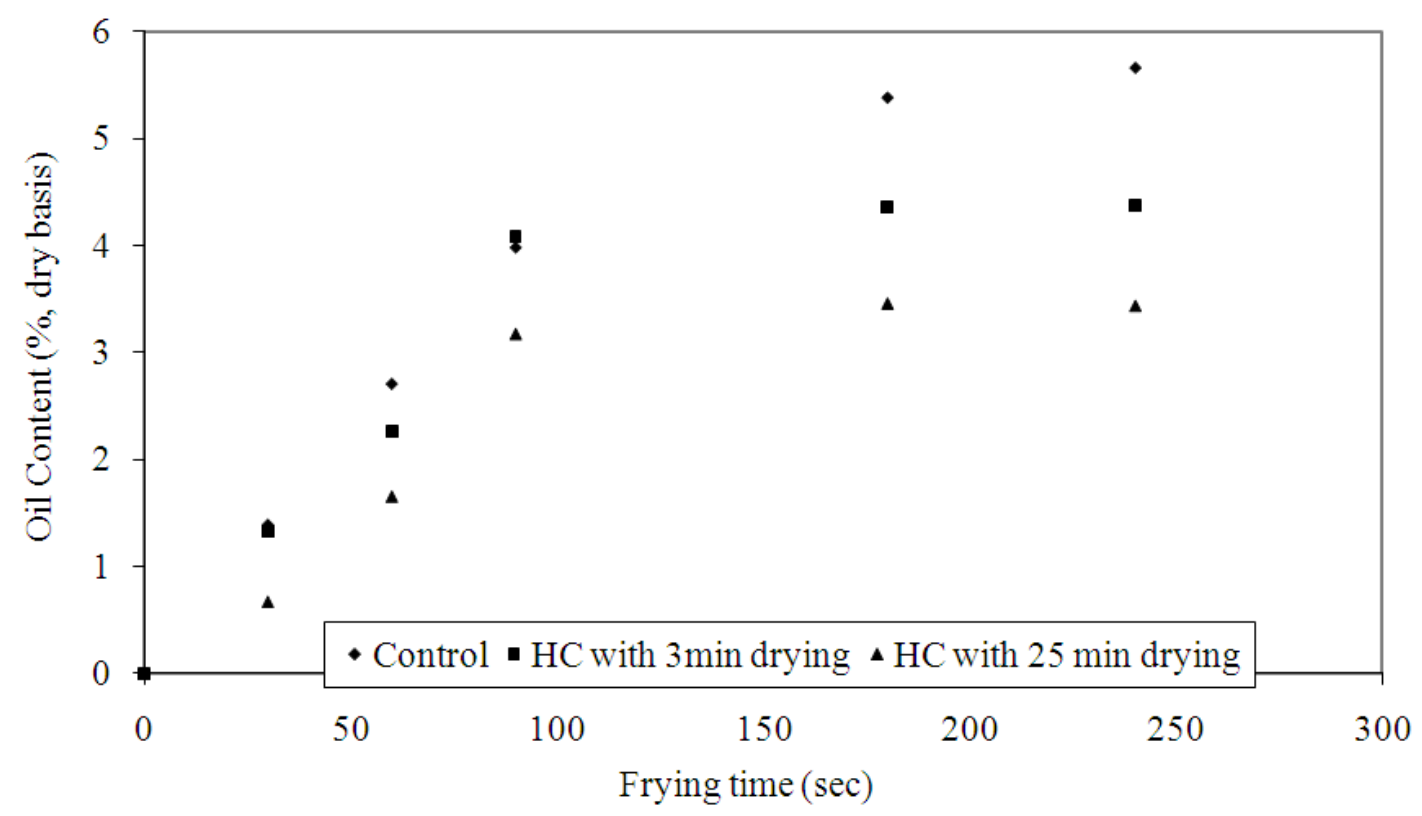

Fig. 1. Oil content in control and samples pre dried and soaked in hydrocolloid system after frying at $160^{\circ} \mathrm{C}$ (potato cylinder-40 $\mathrm{mm}$ length, $12 \mathrm{~mm}$ diameter) 


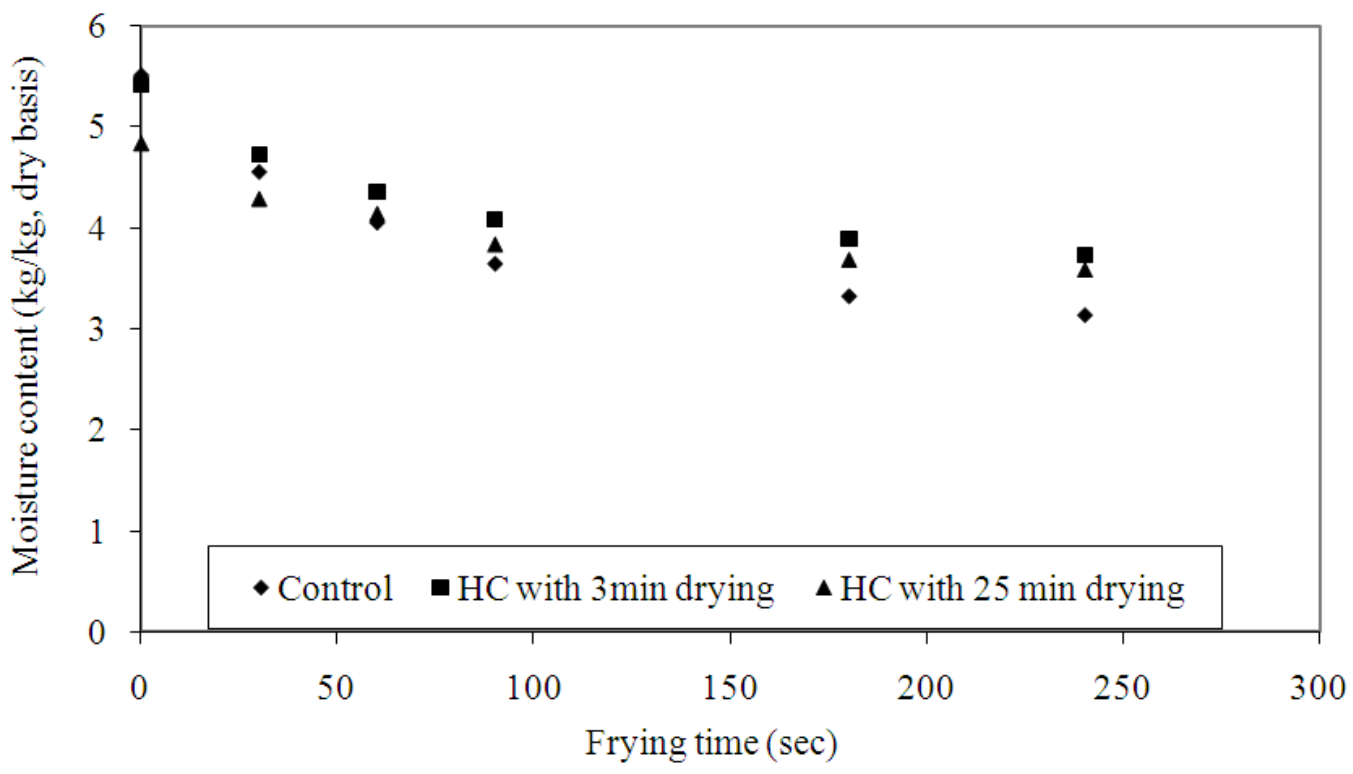

Fig. 2. Moisture content in control and samples pre dried and soaked in hydrocolloid system after frying at $160^{\circ} \mathrm{C}$ (potato cylinder-40 $\mathrm{mm}$ length, $12 \mathrm{~mm}$ diameter)

Table 1. Moisture Loss equation and $\mathrm{R}^{2}$ for data shown in Fig. 2

\begin{tabular}{lll}
\hline Sample treatment & Equation* & $\mathrm{R}^{2}$ \\
\hline No Treatment (Control) & $\mathrm{y}=4.03 \mathrm{e}-0.002 \mathrm{x}$ & 0.940 \\
Dipping in hydrocolloid with 3 min drying & $\mathrm{y}=4.97 \mathrm{e}-0.001 \mathrm{x}$ & 0.822 \\
Dipping in hydrocolloid with 25 min drying & $\mathrm{y}=4.511 \mathrm{e}-0.001 \mathrm{x}$ & 0.826 \\
\hline
\end{tabular}

*Equation: $\mathrm{y}= \pm \mathrm{a} \exp (-\mathrm{bx})$, where $\mathrm{y}=$ moisture content $(\mathrm{kg} / \mathrm{kg}$, dry basis), $\mathrm{x}=$ frying time $(\mathrm{sec})$

Table 2. Influence of predrying time in combination with hydrocolloid system on some quality attributes of fried potato

\begin{tabular}{|c|c|c|c|c|c|c|c|c|c|c|}
\hline \multirow[b]{3}{*}{ Treatment } & \multicolumn{3}{|c|}{ Moisture content (kg/kg, dry basis) } & \multicolumn{3}{|c|}{ Fat content (\%, dry basis) } & \multirow{2}{*}{\multicolumn{4}{|c|}{ Color }} \\
\hline & & & & & & & & & & \\
\hline & frying & frying & loss & $\%$ fat & in fat absorption* & cutting force & $\mathrm{L}$ & $\mathrm{a}$ & $\mathrm{b}$ & $\Delta \mathrm{E}$ \\
\hline Control & $\begin{array}{l}5.52 \mathrm{a} \\
62.63 \mathrm{a}\end{array}$ & $3.14 \mathrm{c}$ & $43.12 \mathrm{a}$ & $5.67 \mathrm{a}$ & - & $39.42 \mathrm{a}$ & $60.11 \mathrm{a}$ & $0.35 \mathrm{a}$ & $19.34 \mathrm{a}$ & \\
\hline Predrying for $3 \mathrm{~min}$ & $\begin{array}{l}5.42 \mathrm{a} \\
63.52 \mathrm{a}\end{array}$ & $3.73 \mathrm{a}$ & $31.18 \mathrm{~b}$ & $4.38 \mathrm{~b}$ & $22.75 b$ & $57.89 \mathrm{~b}$ & $60.94 a$ & $0.49 \mathrm{a}$ & $20.98 \mathrm{a}$ & \\
\hline Predrying for $25 \mathrm{~min}$ & $\begin{array}{l}4.84 \mathrm{~b} \\
64.81 \mathrm{a}\end{array}$ & $3.59 \mathrm{~b}$ & $25.83 \mathrm{c}$ & $3.44 \mathrm{c}$ & $39.33 \mathrm{a}$ & $73.42 \mathrm{c}$ & $61.89 \mathrm{a}$ & $0.67 \mathrm{a}$ & $21.71 \mathrm{a}$ & \\
\hline
\end{tabular}

* as compared to control sample

\subsection{Mold Growth}

The samples were tested for the formation of molds. As fried samples were stored at room temperature, the mold formation was expected to be soon. The control sample showed a start of mold formation after $48 \mathrm{~h}(2$ days). This growth was very clear in the 3rd day. The growth was increased rapidly as time increasing in daily base. The fried sample treated with hydrocolloid (predried for $3 \mathrm{~min}$.) showed a steady preservation status during the first $120 \mathrm{~h}$ (5 days). The mold growth was clear after the 5 th day but with minimum growth. For samples treated with hydrocolloid and pre dried for 25 min. the early formation of mold was not before 7 days for samples storage at room temperature. The effect of hydrocolloid was clear in retarding the microbial spoilage and at the same time decreasing this growth to the minimum. This is due to hydrocolloid working as a barrier to moisture and Oxygen decreasing the amount of moisture and oxygen available for mold growth (Gontard et al., 1996). Mold requires much less $a_{w}$ than bacteria thus the expected bacterial growth is to be up to minimum. However, the antimicrobial activity of edible coating can be further improved by incorporating antimicrobial agent with theedible coat. 


\subsection{Texture}

Fried samples obtained by this method had firm texture and were crunchy. This effect was confirmed by the results of the required cutting force presented in Table 2. There were significant differences in texture of samples. As the pre drying time increased, the required cutting force increased which is in agrrement with (Krokida et al., 2001) who reported that predrying before frying significantly affected structural properties of fried potato.

\subsection{Color}

In terms of color, all color parameters increased in partially dried sample, due to browning reactions. However the differences were not significant.

\section{CONCLUSION}

Results in this study indicated that pre drying step enhanced the influence of hydrocolloid on frying characteristics. This could be related to the fact that the effect of hydrocolloid, when it is located within the sample beneath the surface, is better than its adsorption on the surface. Using combination of pre drying treatment (at $69^{\circ} \mathrm{C}$ for $25 \mathrm{~min}$ ) and soaking in hydrocolloid system lead to decrease in oil absorption by $39.33 \%$, increase firmness and decrease moisture loss.

\section{REFERENCES}

Albert, S. and G.S. Mittal, 2002. Comparative evaluation of edible coatings to reduce fat uptake in a deepfried cereal product. Food Res. Int., 35: 445-458. DOI: $10.1016 /$ S0963-9969(01)00139-9

AOAC, 1995. Official Methods of Analysis of AOAC. 16th Edn., Association of Analytical Chemist, Inc., Arlington, VA.

Bravin, B., D. Peressini and A. Sensidoni, 2004. Influence of emulsifier type and content on functional properties of polysaccharide lipid-based edible films. J. Agric. Food Chem., 52: 6448-6455. DOI: $10.1021 /$ jf040065b

Bravin, B., D. Peressinin and A. Sensidoni, 2006. Development and application of polysaccharidelipid edible coating to extend shelf-life of dry bakery products. J. Food Eng., 76: 280-290. DOI: 10.1016/j.jfoodeng.2005.05.021

Bunger, A., P. Moyano and V. Rioseco, 2003. $\mathrm{NaCl}$ soaking treatment for improving the quality of French-fried potatoes. Food Res. Int., 36: 161-166. DOI: $10.1016 /$ S0963-9969(02)00131-X
Cuq, B., C. Aymard, J.L. Cuq and S. Guilbert, 1995. Edible packaging films based on fish myofibrillar proteins: Formulation and functional properties. J. Food Sci., 60: 1369-1374. DOI: 10.1111/j.13652621.1995.tb04593.x

Farkas, B.E., R.P. Singh and T.R. Rumsey, 1996. Modeling heat and mass transfer in immersion frying. I, model development. J. Food Eng., 29: 211226. DOI: 10.1016/0260-8774(95)00072-0

Garmakhany, A.D., H.O. Mizaei, Y. Maghsoudlou, M. Kashaninejad and S.M. Jafari, 2010. Influence of partial drying on oil uptake and quality attributes of french fries. J. Agric. Sci. Technol., 4: 41-46.

Gontard, N., R. Thibault, B. Cuq and S. Guilbert, 1996. Influence of relative humidity and film composition on oxygen and carbon dioxide permeabilities of edible films. J. Agric. Food Chem., 44: 1064-1069. DOI: $10.1021 /$ jf9504327

Guilbert, S., B. Cuq and N. Gontard, 1997. Recent innovations in edible and/or biodegradable packaging materials. Food Addit. Contam., 14: 741-751. DOI: 10.1080/02652039709374585

Kester, J.J. and O.R. Fennema, 1986. Edible films and coatings: A review. Food Technol., 40: 47-59.

Krokida, M.K., V. Oreopaulon, Z.B. Maroulis and D. Marinos-Kouris, 2001. Deep fat frying of potato strips-quality issues. Drying Technol., 19: 879-935. DOI: 10.1081/DRT-100103773

Moreno, M.C. and P. Pouchon, 2008. A different perspective to study the effect of freeze, air and osmotic drying on oil absorption during potato frying. J. Food Sci., 37: E122-E128. DOI: 10.1111/j.1750-3841.2008.00669.x

Ouchon, P.B. and D.L. Pyle, 2004. Studying oil absorption in restructured potato chips. J. Food Sci., 69: FEP115-FEP122. DOI: 10.1111/j.13652621.2004.tb13363.x

Rimac-Brncic, S., V. Lelas, D. Rade and B. Simundic, 2004. Decreasing of oil absorption in potato strips during deep fat frying. J. Food Eng., 64: 237-241. DOI: 10.1016/j.jfoodeng.2003.10.006

Weber, C.J., 2000. Biobased Packaging Materials for the Food Industry: Status and Perspectives: A European Concerted Action. 1st Edn., KVL Department of Dairy and Food Science, Frederiksberg, ISBN-10: 8790504070, pp: 136. 